\title{
Rasio Kecukupan Pemenuhan Modal Minimum (KPPM) terhadap Eksposur Aktiva Tertimbang Menurut Risiko (ATMR) Bank Syari'ah
}

\author{
Suci Maughfiroh \\ Perbankan Syariah, Fakultas Ekonomi dan Bisnis Islam, Universitas Nurul Jadid, Indonesia \\ Email: sucimaughfiroh1073@gmail.com
}

\begin{abstract}
:
The banking world is inseparable from the aspect of capital. In running a business, capital is needed. Capital is a driving factor of various sectors of activity. In order for banks to develop healthily and be able to compete in international banking, bank capital must always follow the applicable international standards, which are determined by Banking For Internasional Sattlement (BIS) i.e. (CAR) by $8 \%$. The purpose of this study is to review or analyze the Minimum Capital Adequacy Ratio (KPPM) to the Risk Weighted Assets (ATMR) of BNI Syari'ah 2018. To find out the bank can meet its capital well or not with the risk constraints that may arise from the assets owned. The results showed that the BNI Syariah Capital Adequacy Ratio Percentage was $19.24 \%$ from the comparison of Capital and Reserves with Risk Weighted Assets (ATMR). In need of an increase in the Minimum Capital Adequacy Ratio (KPPM) in BNI Syariah banks so that the bank can fulfill all obligations or minimize losses from the risks that occur.
\end{abstract}

Keywords: Capital Adequacy Ratio Risk Weighted Assets.

\begin{abstract}
Abstrak:
Dunia perbankan tidak terlepas dari aspek pemodalan. Dalam menjalankan suatu usaha maka di perlukanlah modal. Modal merupakan faktor penggerak dari berbagai sektor kegiatan.Agar perbankan dapat berkembang secara sehat dan mampu bersaing dalam perbankan internasional maka permodalan bank harus senantiasa mengikuti ukuran yang berlaku secara internasional, yang ditentukan oleh Banking For Internasional Sattlement (BIS) yaitu (CAR) sebesar 8\%. Maksud dari penelitian ini adalah mengkaji atau menganalisis Rasio Kecukupan Modal Minimum (KPPM) terhadap Aktiva Tertimbang Menurut Risiko (ATMR) BNI Syari'ah 2018. Untuk mengetahui bank tersebut dapat memenuhi permodalannya dengan baik atau tidak dengan kendala risiko yang mungkin akan timbul dari asset- asset yang dimiliki. Hasil penelitian menunjukkan bahwa Prensentase CAR Capital Adequacy Ratio BNI Syariah sebesar 19,24\% dari hasil perbandingan Modal dan Cadangan dengan Aktiva Tertimbang Menurut Risiko (ATMR). Di perlukannya suatu peningkatan Rasio Kecukupan Modal Minimum (KPPM) di bank BNI syariah agar bank tersebut dapat memenuhi semua kewajiban atau meminimalisir kerugian dari risiko yang terjadi.
\end{abstract}

Kata Kunci: KPPM, ATMR. 


\section{PENDAHULUAN}

Dalam dunia perbankan sangat kental dengan kegiatan penghimpunan dana atau penyaluran dana bahkan jasa. Dasar utama kegiatan perbankan adalah kepercayaan (trust), baik dalam hal penghimpunan dana maupun dalam penyaluran dana masyarakat akan mau menitipkan dananya di bank apabila dilandasi oleh unsur kepercayaan. Masyarakat percaya sepenuhnya bahwa uangnya tidak akan di salahgunakan dan begitu sebaliknya bank menyalurkan dananya kepada debitur karena bank percaya debitur akan megembalikanya pada jatuh tempo yang ditentukan. Maka dari hal tersebut apabila terjalin sedemikian rupa maka operasional bank tidak akan terganggu.

Dari beberapa kegiatan di atas tentunya bank membutuhkan yang namannya modal. Bank sebagai intermediasi antara penanam modal dengan pencari modal. Dalam kegiatannya bank menciptakan aktiva baik milik sendiri, dana pihak ketiga, atupun pinjaman.Tolok ukur permodalan dalam perbankan yaitu perhitungan penyediaan modal minimum (capital adequacy) didasarkan pada Aktiva Tertimbang Menurut Risiko (ATMR). Berdasarkan ketentuan Bank Indonesia, bank yang dinyatakan termasuk sebagai bank yang sehat harus memiliki CAR paling sedikit sebesar 8\%. Hal ini didasarkan kepada ketentuan yang ditetapkan oleh Bank Indonesia sebagai standart tingkat kesehatan bank untuk permodalan'1.

Setiap penciptaan aktiva, disamping berpotensi menghasilkan keuntungan juga berpotensi menimbulkan terjadinya risiko. Oleh karena itu modal juga harus dapat digunakan untuk menjaga kemungkinan terjadinya risiko kerugian atas aktiva dan investasi pada aktiva, terutama yang berasal dari dana-dana pihak ketiga atau masyarakat. Bank syari'ah sebagai unit bisnis maksudnya adalah bank syariah merupakan sebuah lembaga keuangan yang penerapanya sistem bagi hasil dan tanpa bunga namun dalam bank syari'ah juga mengenal keuntungan yang mana berbaentuk nisbah. Dan setiap usaha atau bisnis tidak selalu berpaku pada keuntungan akan tetapi terdapat risiko-risiko yang mungkin terjadi termasuk bank syari'ah juga akan menghadapi risiko manajemen bank itu sendiri. Bahkan, apabila dicermati secara mendalam, bank syariah merupakan bank yang rentan akan risiko, karena ketidapastian dalam mendapatkan laba yang sering di sebut kontijensi. Bank syari'ah dalam operasionalnya sangat memerhatikan sektor rill jadi apapun masalah yang terjadi akan berdampak juga terhadap bank syari'ah semisal terjadi bencana alam atau keadaan memaksa (Force Majure) lain yang membuat nasabah tidak bisa memenuhi kewajibannya sehingga hal tersebut sangat berisiko bagi perbankan².

Produk pembiayaannya sangat berisiko karena dari kegiatan bank syariah dalam mengambil keuntungan berpaku pada sektor riil dan untuk menanggulangi hal - hal yang menimbulkan risiko besar bagi bank maka biasanya bank melakukan analisis sebelum menyalurkan dananya baik melalui produk mudharabah atau yang lainya. Bank syari'ah harus benar- benar memanage kegiatan bank dari berbagai aspek dan yang paling utama adalah aspek pemodalan karena dalam perbankan modal itu sangat penting karena sebagai

\footnotetext{
${ }^{1}$ Seandy Nandadipa and PRASETIONO, "Analisis Pengaruh CAR, NPL, Inflasi, Pertumbuhan DPK, Dan Exchange Rate Terhadap LDR (Studi Kasus Pada Bank Umum Di Indonesia Periode 2004-2008),,' Universitas Diponegoro, 2010.

${ }^{2}$ Muhammad Iqbal Fasa, "Manajemen Resiko Perbankan Syariah Di Indonesia," Li Falah: Journal of Islamic Economics and Business Studies 1.2 (2017): 36-53.
}

Iqtishadia: Jurnal Ekonomi dan Perbankan Syariah

Vol. 7 No. 2 Desember 2020 
Suci Maugfiroh

penggerak operasional yang dilakukan bank tersebut. Didalam Aspek permodalan bank dapat diproksi dengan rasio kecukupan penyediaan modal minimum bank (KPMM) atau Capital Adequacy Ratio (CAR).

Rasio Kecukupan Pemenuhan Modal Minimum (KPPM) Aspek permodalan bank dapat diprediksi dengan rasio kecukupan pemenuhan modal minimum bank (KPMM) atau capital adequacy ratio (CAR). dengan adanya ketetapan rasio kecukupan modal bank menjadi tolak ukur kesehatan bank. Menurut Mudrajad Kuncoro dan Suhardjono Rasio Kecukupan Modal (CAR) adalah kecukupan modal yang menunjukan kemampuan bank dalam mempertahankan modal yang mencukupi dan kemampuan manajemen bank dalam mengidentifikasi, mengukur, mengawasi, dan mengontrol risiko-risiko yang timbul yang dapat berpengaruh terhadap besarnya modal bank. Dengan kata lain, capital adequacy ratio adalah risiko kinereja bank untuk mengukur kecukupan modal yang dimiliki bank untuk menunjang aktiva yang mengandung atau menghasilkan risiko misalnya kredit yang diberikan ${ }^{3}$.

Rasio keceukupan modal (CAR) di dalam intansi perbankan seseuai dengan peraturan yang telah di tetapkan BIS yang berlaku di Indonesia besarnya Rasio kecukupan modal (CAR) suatu bank ditentukan oleh seberapa besar modal yang dimiliki yang terdiri dari modal inti dan modal pelengkap, serta berapa aktiva tertimbang menurut risiko, di mana bobot risiko masing- masing aktiva telah ditetapkan oleh Banking For Internasional Sattlement (BIS).

Modal didalam perbankan merupakan faktor yang paling penting karena bagimana bank itu bisa berjalan melaksanakan kegiatannya baik itu dari segi penghimpunan dana ataupun penyaluran dana sedangkan dari bank itu sendiri tidak memiliki modal. Jadi modal itu sebagai sistem motorik bagi bank dan modal juga menjadi tolak ukur kemajuan sekaligus menjaga kepercayaan masyarakat terhadap bank tersebut.

BIS menetapkan ketentuan perhitungan Capital Edequecy Ratio (CAR) yang harus diikuti oleh bank bank di seluruh dunia sebagai aturan main dalam kompetisi yang fair di pasar keuangan global, yaitu rasio minimum $8 \%$ permodalan terhadap aktiva berisiko. Aktiva Tertimbang Menurut Risiko (ATMR) Bank Syariah merupakan risiko atas modal berkaitan dengan dana yang diinvestasikan pada aktiva berisiko rendah ataupun yang risikonya lebih tinggi dari yang lain. Aktiva Tertimbang Menurut Risiko diperoleh dari nilai total masingmasing aktiva bank setelah dikalikan dengan masing-masing bobot risiko aktiva tersebut. Aktiva yang paling tidak berisiko diberi bobot $0 \%$ dan aktiva yang paling berisiko diberi bobot $100 \% 4$.

Dengan demikian ATMR bank syari'ah dari kegiatan bank yaitu dana yang di investasikan beragam ada yang berisiko rendah ada yang berisiko tinggi dan untuk menjaga stabilitas keuangan bank maka di perlukannya jumlah modal yang cukup. Aktiva yang didanai oleh modal sendiri dan kewajiban atau utang, risikonya ditanggung oleh modal sendiri, sedangkan aktiva yang didanai oleh rekening bagi hasil, risikonya ditanggung oleh dana rekening bagi hasil itu sendiri. Namun demikian, sebagaimana diuraikan diatas, pemilik rekening bagi hasil dapat menolak untuk menanggung risiko atas aktiva yang dibiayainya, apabila terbukti bahwa risiko tersebut timbul akibat salah urus (mis management), kelalaian atau kecurangan yang dilakukan oleh mangemen bank selaku mudharib.

\footnotetext{
${ }^{3}$ Mudrajat Kuncoro and Suhardjono, Manajemen Perbankan (Yogyakarta: BPFE, 2011), 519.

${ }^{4}$ Khaerul umam, Manajemen Perbankan Syariah (Bandung: CV Pustaka setia, 2013), 251.
} 
Rasio Kecukupan Pemenuhan Modal Minimum (KPPM) terhadap Eksposur Aktiva Tertimbang Menurut Risiko (ATMR) Bank Syari'ah

Dengan mengetahui rasio kecukupanPemenuhan modal minimum suatu bank nasabah ataupun investor akan percaya untuk menanamkan dananya kepada pihak bank. Bank yang di katakan sehat apabila hasil pengukuran modalnya melebihi standar rasio kecukupan pemenuhan modal maka bank tersebut dapat mengesponsur asset tertimbang menurut risiko.

\section{METODE PENELITIAN}

Berdasarkan data yang telah diteliti dan model penelitian yang telah disusun, maka penelitian ini menggunakan penelitian kualitatif untuk menjawab rumusan masalah. Karena proses penelitiannya lebih bersifat seni (tidak terpola) dan data hasil penelitiannya lebih bersifat interpretasi terhadap data yang ditemukan di lapangan. Peneliti memahami teoriteori yang di kumpulkan sesuai dengan judul penelitian kemudian diarahkan dengan fakta di lapangan.

Dari landasan teori diatas yang mencakup tentang rasio Kecukupan Pemenuhan Modal Minimum (KPMM) terhadap Aset Tertimbang Menurut Resiko (ATMR) Bank syari'ah peneliti menganalisis data dari Laporan BNI Syari'ah 2018 untuk mengidentifikasi rasio Kecukupan Pemenuhan Modal Minimum (KPMM) terhadap Aset Tertimbang Menurut Resiko (ATMR) Bank syari'ah.

Hubungan antrar variabel bersifal holistic yang mana objeknya Rasio Kecukupan Modal Minimum (KPPM) dan Aktiva Tertimbang Menurut Risiko (ATMR) Bank Syariah saling beriteraktif (saling mempengaruhi)

Proses penelitian Penelitian Kuantitatif sebaliknya, peneliti sudah tahu apa, mengapa dan bagaimana Rasio Kecukupan Modal Minimum (KPPM) dan Aktiva Tertimbang Menurut Risiko (ATMR) penekanan penelitiannya lebih kepada seberapa besar misalnya pengaruh terhadap kedua variabel tersebut di lapangan.

\section{HASIL DAN PEMBAHASAN}

PT Bank BNI Syariah (selanjutnya disebut BNI Syariah atau Perseroan) merupakan hasil proses spin off dari Unit Usaha Syariah (UUS) PT Bank Negara Indonesia (Persero) Tbk yang telah beroperasi sejak sejak 29 April 2000. Proses spin off dilandasi oleh terbitnya UU No. 21 tahun 2008 tentang Perbankan Syariah.

BNI Syariah secara resmi beroperasi pada 19 Juni 2010 setelah mendapat Surat Keputusan Gubernur Bank Indonesia No. 12/41/KEP. GBI/2010 tanggal 21 Mei 2010, setelah sebelumnya pendirian Perseroan telah ditetapkan berdasarkan Akta No.160 dan telah disahkan melalui Surat Keputusan Menteri Hukum \& HAM Nomor: AHU-15574, AH.01.01 Tahun 2010, Tanggal 25 Maret 2010. 20185:

Dibawah ini merupakan data yang dihasilkan dari Laporan BNI syari'ah Pada tahun

Gambar 1.

Laporan Perhitungan KPPM

\footnotetext{
${ }^{5}$ BNI Syari'ah, "Laporan Keuangan PT Bank BNI Syari’ah,” diakse dari www.bnisyariah.co.id pada tanggal desember 2019.
}

Iqtishadia: Jurnal Ekonomi dan Perbankan Syariah

Vol. 7 No. 2 Desember 2020 
LAPORAN PERHITUNGAN KEWAJBAN PENYEDIAAN MODAL MINIMUM (KPPM) Tanggal Laporan 30 Juni 2018 dan 30 juni 2017 (Dalam Jutaan Rupiah)

NO KOMPONEN MODAL

Modal Inti (Tier 1)

1. Modal Inti Utama (CET 1)

1.1 Modal Disetor (stelah dikurangi saham treasury)

1.2 Cadangan Tambahan Modal

1.2.1 Faktor Penambah

1.2.1.1 Penghasilan Komprehensif lain

1.2.1.1.1 Selisih Lebih Penjabaran Laporan Keuangan

1.2.1.1.2 Potensi Keuntungan dari peningkatan nilai wajar aset keuangan dalam kelompok tersedia untuk di jual

1.2.1.2.2 Cadangan Umum

1.2.1.2.3 Laba tahun-tahun lalu setelah di perhitungkan pajak

1.2.1.2.4 Laba tahun berjalan setelah di perhitungkan pajak

1.2.1.2.5 Dana setoran modal

1.2.1.2.6 Modal sumbangan

1.2.1.2.7 Waran yang di terbitkan

1.2.1.2.8 Opsi saham yang di terbitkan dalam rangka kompensasi berbasis saham
2.305

43.838

1.464 .074

150.150

1.110 .935

30 JUNI 2018

30 JUNI 2017

3.917.825

2.602.294

1.501 .500

1.168 .350

1.220 .861

48.946

5.108

43.838

1.171 .915

92.853

861.547

202.989

217.515

Iqtishadia: Jurnal Ekonomi dan Perbankan Syariah

Vol. 7 No. 2 Desember 2020 
Rasio Kecukupan Pemenuhan Modal Minimum (KPPM) terhadap Eksposur Aktiva Tertimbang Menurut Risiko (ATMR) Bank Syari'ah

1.2.2.1.1 Selisih kurang penjabaran laporan keuangan

1.2.2.1.2 Potensi kerugian dari penurunan nilai wajar aset keuangan dalam kelompok tersedia untuk dijual

1.2.2.2 Cadangan dan tambahan modal lainnya (other disclosed reserves)

1.2.2.2.1 Disagio saham biasa

1.2.2.2.2 Rugi tahun-tahun lalu yang dapat di perhitungkan

1.2.2.2.3 Rugi tahun berjalan yang dapat diperhitungkan

1.2.2.2.4 Selisih kurang antara Penyisihan Penghapusan Aset (PPA) dan cadangan kerugian penurunan nilai (CKPN) atas aset produktif

1.2.2.2.5 Selisih kurang jumlah penyesuian nilai wajar dari instrumen keuangan dalam Tranding Book

1.2.2.6 PPA atas aset non produktif yang wajib di bentuk

1.3 Kepentingan Non Pengendali yang dapat diperhitungkan

\subsection{Faktor Pengurang Modal Inti Utama}

1.4.1 Perhitungan pajak tangguhan

1.4.2 Goodwill

1.4.3 Seluruh aset tidak terwujud lainnya

1.4.4 Penyertaan yang diperhitungkan sebagai faktor pengurang

1.4.5 Kekurangan modal pada perusahaan anak asuransi

\subsubsection{Eksposur sekuritisasi}

1.4.7 Faktor pengurang modal inti

1.4.7.1 Penempatan dana pada instrument AT1 dan/atau Tier 2 pada bank lain

\section{Modal Inti Tambahan/ Additional Tier 1(AT-1)}

2. 1 Instrumen yang memenuhi persyaratan AT-1

2.2 Agio (Disagio) (+/-)

Iqtishadia: Jurnal Ekonomi dan Perbankan Syariah Vol. 7 No. 2 Desember 2020 
2.3 Faktor Pengurang Modal Inti Tambahan

2.3.1 Penempatan dana pada instrumen AT1 dan/ atau Tier 2 pada bank lain

II Modal Pelengkap (Tier 2)

1. Instrumen modal dalam bentuk saham atau lainnya yang memenuhi persyaratan Tier 2

2. Agio/ Disagio

3. Cadangan umum PPA atas aset produktif yang wajib di bentuk (paling tinggi 1,25 \% ATMR resiko kredit)

4. Cadangan tujuan

5. Faktor pengurang modal pelengkap

(96.000)

(96.000)

5.1 Sinking Fund

5.2 Penempatan dana pada instrumen Tier 2 pada bank lain

(96.000)

(96.000)

TOTAL MODAL

4.036.748

ASET TERTIMBANG MENURUT RESIKO

ATMR RESIKO KREDIT

ATMR RESIKO PASAR

ATMR RESIKO OPERASIONAL

TOTAL ATMR

RASIO KPMM SESUAI PROFIL RESIKO (\%)

ALOKASI PEMENUHAN KPMM SESUAI PROFIL RESIKO

Dari CET 1 (\%)

Dari AT 1 (\%)

Dari Tier 2 (\%)
17.171 .921

45.252

3.761 .955

20.979 .128

$9,39 \%$

$9,37 \%$

$8,82 \%$

$8,84 \%$

$0,00 \%$

$0,00 \%$

$0,57 \%$

$0,53 \%$
15.599. 398

58.847

3.193 .5

18.851.

762 
Rasio Kecukupan Pemenuhan Modal Minimum (KPPM) terhadap Eksposur Aktiva Tertimbang Menurut Risiko (ATMR) Bank Syari'ah

\begin{tabular}{|lcr|}
\hline Rasio CET 1 (\%) & $18,67 \%$ & $13,80 \%$ \\
Rasio Tier 1 (\%) & $18,67 \%$ & $13,80 \%$ \\
Rasio Tier 2 (\%) & $0,57 \%$ & $0,53 \%$ \\
Rasio KPMM (\%) & $19,24 \%$ & $4,96 \%$ \\
CET 1 UNTUK BUFFER (\%) & $9,85 \%$ & $0,00 \%$ \\
PROSENTASE BUFFER YANG WAJIB DI PENUHI OLEH BANK (\%) & & $0,00 \%$ \\
Capital Conservation Buffer (\%) & $0,00 \%$ & $0,00 \%$ \\
\hline Countercyclical Buffer (\%) & $0,00 \%$ & \\
Capital Sucharge untuk Bank Sistemik (\%) & $0,00 \%$ & \\
\hline
\end{tabular}

Modal didefinisikan sebagai sesuatu yang mewakili kepentingan pemilik dalam suatu perusahaan ${ }^{6}$. Berdasarkan nilai buku, modal didefinisikan sebagai kekayaan bersih (net worth), yaitu selisih antara nilai buku dari aktiva dikurangi dengan nilai buku dari kewajiban (liabilities). Menurut zainul, modal merupakan kakayaan bersih yang dimiliki perusahaan setelah di kurangi kewajiban. Menurut Suharjono komponen modal yang digunakan dalam perhitungan penyediaan modal minimum terdiri atas:

a. Modal tier 1, yaitu modal inti, yang terdiri atas modal disetor, premi saham, laba ditahan, cadangan minimum.

b. Modal tier 2, yaitu modal tambahan, yang terdiri atas cadangan yang tidak diungkapkan, revaluasi, provisi umum, dan utang subordinasi yang jatuh tempo lebih dari lima tahun.

Berdasarkan ketentuan yang dibuat Bank Indonesia dalam rangka tata cara penilaian tingkat kesehatan bank, terdapat ketentuan bahwa modal bank terdiri atas modal inti dan modal pelengkap. Sejalan dengan Mulyono, modal bank terdiri atas modal inti dan modal pelengkap.

1) Modal inti

Modal Inti adalah jenis modal yang terdapat dalam komponen modal dan merupakan bagian terpenting dalam bank. Apabila terdapat goodwill maka perhitungan atas jumlah seluruh modal inti harus dikurangi dengan goodwill tersebut. Modal inti terdiri atas:

a) Modal disetor adalah modal yang telah disetor secara efektif oleh pemiliknya (pemegang saham) bagi bank yang berbadan hukum. Koperasi modal disetor terdiri atas simpanan pokok dan simpanan wajib anggotanya.

b) Agio saham adalah selisih lebih setoran modal yang diterima oleh bank sebagai akibat dari harga saham yang melebihi nilai nominalnya.

\footnotetext{
${ }^{6}$ Zainul Arifin, Dasar-Dasar Manajemen Perbankan Syariah (Jakarta: Alfabeta, 2002), 157.
}

Iqtishadia: Jurnal Ekonomi dan Perbankan Syariah

Vol. 7 No. 2 Desember 2020 
Suci Maugfiroh

c) Cadangan umum adalah cadangan yang dibentuk dari penyisihan laba ditahan atau laba bersih setelah dikurangi pajak dan mendapat persetujuan Rapat Umum pemegang Saham (RUPS) atau rapat anggota sesuai anggaran dasar masing-masing.

d) Cadangan tujuan adalah bagian laba setelah dikurangi pajak yang disisihkan untuk tujuan tertentu dan telah mendapat persetujuan dari Rapat Umum Pemegang Saham (RUPS) atau rapat anggota.

e) Laba ditahan adalah saldo laba bersih setelah dikurangi pajak, yang oleh Rapat Umum Pemegang Saham (RUPS) atau rapat anggota diputuskan untuk tidak dibagikan.

f) Laba tahun lalu adalah laba bersih tahun-tahun lalu setelah dikurangi pajak dan belum ditentukan penggunaannya oleh Rapat Umum Pemegang Saham (RUPS) atau rapat anggota. Jumlah laba tahun lalu yang diperhitungkan sebagai modal inti hanya sebesar 50\%. Jika bank mempunyai saldo rugi pada tahun-tahun lalu, seluruh kerugian tersebut menjadi faktor pengurang dari modal inti.

g) Laba tahun berjalan adalah laba yang diperoleh dalam tahun buku berjalan setelah dikurangi taksiran utang pajak. Jumlah laba tahun buku berjalan yang diperhitungkan sebagai modal inti hanya sebesar 50\%. Jika bank mempunyai saldo rugi pada tahuntahun lalu, seluruh kerugian tersebut menjadi faktor pengurang dari modal inti.

h) Bagian kekayaan bersih anak perusahaan yang laporan keuangannya dikonsolidasikan (minority interest) adalah bagian kekayaan bersih anak perusahaan yang laporan keuangannya yang dikonsolidasikan yaitu modal inti anak perusahaan setelah dikompensasikan dengan nilai penyertaan bank pada anak perusahaan tersebut. Yang dimaksud anak perusahaan adalah bank lain, lembaga keuangan atau lembaga pembiayaan (Lembaga Keuangan Bukan Bank / LKBB) yang mayoritas sahamnya dimiliki oleh bank.

2) Modal Pelengkap

Modal pelengkap yaitu modal yang terdiri dari cadangan-cadangan yang dibentuk tidak dari laba setelah pajak, serta pinjaman yang sifatnya dapat dipersamakan dengan modal, modal pelengkap dapat berupa: ${ }^{7}$

a) Cadangan revaluasi aktiva tetap adalah cadangan yang dibentuk dari selisih penilaian kembali aktiva tetap yang telah mendapat persetujuan Direktorat Jenderal Pajak.

b) Cadangan Penyisihan Penghapusan Aktiva Produktif (PPAP) adalah cadangan yang dibentuk dengan cara membebani laba-rugi tahun berjalan, dengan maksud untuk menampung kerugian yang mungkin timbul sebagai akibat dari tidak diterimanya kembali sebagian atau seluruh aktiva produktif. Dalam kategori cadangan ini termasuk cadangan piutang ragu-ragu dan cadangan penurunan \nilai surat-surat berharga. Jumlah cadangan penghapusan aktiva yang diklasifikasikan yang dapat diperhitungkan sebagai komponen modal pelengkap adalah maksimum sebesar 12,5\% dari jumlah Aktiva Tertimbang Menurut Risiko (ATMR).

c) Modal kuasi adalah modal yang didukung oleh instrumen atau warkat yang memiliki sifat seperti modal atau hutang yang mempunyai ciri-ciri:

1) Tidak dijamin oleh bank yang bersangkutan, dipersamakan dengan modal (subordinated) dan telah dibayar penuh.

\footnotetext{
${ }^{7}$ Khaerul umam, Manajemen Perbankan Syariah, 342-43.
} 
2) Tidak dapat dilunasi atau ditarik atas inisiatif pemilik, tanpa persetujuan Bank Indonesia.

3) Mempunyai kedudukan yang sama dengan modal dalam hal jumlah kerugian bank melebilihi laba yang ditahan dan cadangan-cadangan yang termasuk modal inti meskipun bank belum dilikuidasi.

Pembayaran bunga dapat ditangguhkan apabila bank dalam keadaan rugi atau labanya tidak mendukung untuk membayar bunga tersebut. Dalam pengertian modal kuasi ini termasuk cadangan modal yang berasal dari penyetoran modal yang efektif oleh pemilik bank yang belum didukung oleh modal dasar (yang sudah mendapat pengesahan dari instansi yang berwenang) yang mencukupi.

Agar perbankan dapat berkembang secara sehat dan mampu bersaing dalam perbankan internasional maka permodalan bank harus senantiasa mengikuti ukuran yang berlaku secara internasional, yang ditentukan oleh Banking For Internasional Sattlement (BIS) yaitu Capital Adequacy Ratio (CAR) sebesar 8\%. Tingkat kecukupan modal bank ini dapat diukur dengan cara membandingkan modal dengan dana-dana pihak ketiga serta membandingkan modal dengan aktiva berisiko ${ }^{8}$.

Membandingkan modal dengan dana-dana pihak ketiga Dilihat dari sudut perlindungan kepentingan para deposan, perbandingan antara modal dengan pos-pos pasiva merupakan petunjuk tentang tingkat keamanan simpana masyarakat pada bank. Perhitungnya merupakan rasio modal dikaitkan dengan simpanan pihak ketiga (giro, deposio, dan tabungan)

$$
\text { (modal dan cadangan)/(giro+deposito+tabungan) }=10 \%
$$

Dari perhitungan tersebut diketahui bahwa rasio modal atas simpanan cukup dengan $10 \%$ dan dengan rasio itu permodalan bank dianggap sehat. Ratio antara modal dan simpanan masyarakat harus di padukan dengan memperhitungkan aktiva yang mengandung risiko. Oleh karena itu, modal harus dilengkapi oleh berbagai cadangan sebagai penyangga modal, sehingga secara umum modal bank terdiri dari modal inti dan modal pelengkap.

Selanjutnya ukuran kedua, yaitu membandingkan modal dengan aktiva berisiko inilah yang dewasa ini menjadi kesepakatan BIS yaitu organisasi bank sentral dari Negaranegara maju.Kesepakatan tentang ketentuan permodalan itu dicapai pada tahun 1988, dengan menetapkan CAR, yaitu ratio minimum yang berdasarkan kepada perbandingan antara modal dengan aktiva berisiko sebesar $12 \%$.

BNI Syari'ah memiliki Total mencapai Rp.37,77 Triliun, meningkat 22,86\% dibandingkan tahun sebelumnya. Dana Pihak Ketiga (DPK) Dana Pihak Ketiga tumbuh 21,48\% menjadi Rp32,39 Triliun. Total Pembiayaan tahun 2018 mencapai Rp25,12 Triliun, meningkat 11,39\% dibandingkan tahun sebelumnya. Laba Bersih BNI Syariah tahun 2018 meningkat 22,96\% menjadi Rp4 202,99 Miliar.

Deskripsi diatas merupakan gambaran umum Laporan Keuangan BNI Syariah dari bebagai aspek. Pembahasan hasil penelitian ini akan memfokuskan pada aspek pemodalan.Dari data Laporan keuangan BNI Syari'ah dapat di identivikasikan modal BNI Syari'ah Terdiri dari Modal inti (Tier 1) dan Modal pelengkap (Tier 2). Modal inti (Tier 1)

\footnotetext{
${ }^{8}$ Dendawijaya Lukman, , Menajemen Perbankan (Bogor: Ghalia Indonesia, 2005), 251.
}

Iqtishadia: Jurnal Ekonomi dan Perbankan Syariah

Vol. 7 No. 2 Desember 2020 
Suci Maugfiroh

teridiri dari 2 bagian .Pertama, Modal inti utama (CET 1) Rp. 3.917.825.000.000 hasil jumlah dari modal di setor Rp. 2.501.500.000.000 dan cadangan tambahan modal sebesar Rp. 1.504.004.000.000 kemudian di kurangi dengan faktor pengurang modal inti utama sebesar Rp.87.679.000.000. Kedua, Modal Tambahan (Buffer) Rp. 0. Modal pelengkap (Tier 2) yang terdiri dari Instrument modal, Agio, Cadangan umum, Cadangan tujuan, dan Faktor pengurang modal pelengkap sehingga jumlahnya mnejadi Rp. 118.923.000.000. Jadi kesimpulannya total modal antara Modal inti (Tier 1) dan Modal pelengkap (Tier 2) adalah Rp. 4.036.748.000.000. Sedangkan dari Aset Tertimbang Menurut Resiko di BNI Syari'ah Terdiri dari ATMR resiko kredit Rp. 17.171.921.000.000, ATMR resiko pasar Rp. 45.252.000.000, dan ATMR resiko operasional Rp.3.761.955.000.000. jadi total Aset Tertimbang Menurut Resiko di Bank BNI Syari'ah Rp. 20.979.128.000.000.

Untuk mengetahui Rasio Kecukupan Modal Minimum (KPPM) atau CAR BNI Syari'ah apakah perbankan tersebut berkembang secara sehat dan mampu bersaing dengan perbankan internasional dengan itu Banking For Internasional Sattlement (BIS) sudah membuat ketetuan untuk semua perbankan dengan mengukur kecukupan modal dengan syarat ketentuan harus melebihi $8 \%$ maka bank tersebut dikatakan sehat karena bank tersebut mampu mempertahankan modalnya dengan bebagai resiko yang timbul. Dalam mengetahui Capital Adequacy Ratio (CAR) dapat di hitung dengan dua cara sebagai berikut :

a. Membandingkan modal dengan dana-dana pihak ketiga.

(modal dan cadangan)/(giro+deposito+tabungan) $=\%$

b. Membandingkan modal dengan aktiva berisiko

(modal dan cadangan)/(aktiva te@rtimbang menurut resiko) = \%

Jadi Rasio Kecukupan Modal Minimum (KPPM) terhadap Aktiva Tertimbang Menurut

Risiko (ATMR) BNI Syari'ah dapat di hitung dengan metode yang kedua dengan membandingkan modal dengan aktiva beresiko sebagai berikut

Di ketahui :

Modal dan cadangan = Rp. 4.036.748.000.000.

Aset Tertimbang Menurut Resiko = Rp. 20.979.128.000.000.

CAR = (modal dan cadangan) $/$ (aktiva te@rtimbang menurut resiko) $\quad$ x $100 \%$ $=(4.036 .748 .000 .000.) /(20.979 .128 .000 .000.) \quad \mathrm{x} 100 \%$

$=0,192 \times 100 \%$

$=19,24 \%$

Jadi Rasio Kecukupan Modal Minimum (KPPM) atau Capital Adequacy Ratio (CAR) sebesar $19.24 \%$. Di Negara Indonesia kecukupan modal atau CAR perbankan semakin meningkat. Hal tersebut dapat dilihat dari data rata-rata CAR perbankan per akhir 2018 secara industri sudah menembus $23,32 \%$. Posisi tersebut terus merangkak naik, hingga per April 2019 lalu CAR menebal ke level 23,47\%.

Dilihat dari asset Di BNI syari'ah yang paling berisiko adalah kredit yang bersumber dari produk penyaluran dana baik dari sistem mudharabah (bagi hasil) atau qard (pinjaman). Dari segi operasionalnya risiko yang terjadi di BNI syari'ah berfokus pada sektor riil dan distribusi laba yang diterima. Sedangkan dari sektor pasar persaingan semakin bekembang jika Di BNI syari'ah hanya bersifat flat tidak melakukan beberapa pembaruan untuk menyaingi bank yang lain maka para nasabah atau investor akan lari kemudian bank akan mendapatkan kerugian yang besar. 
Berdasarkan hasil penelitian, BNI syari'ah perlu meningkatkan rasio KPPM untuk menanggulangi ATMR dengan cara: Pertama, segi penghimpunan dana pihak ketiga dengan melakukan inovasi produk yang memungkinkan menunjuk sisi yang benar benar syari'ah dengan begitu pemahaman masyarakat akan presepsi yang mengatakan bahwa bank syariah sama saja terlebih lagi pelayanan bank syari'ah susah dan kurang efektif dan inovasi baru terhadap efisiensi bank syari'ah karena pada era digital ini banyak masyarakat yang lebih memilih yang lebih praktis, dengan digital semua bisa kita dapatkan Dengan inovasi baru tersebut menghilangkan keyakinan nasabah akan penilaian produk BNI Syari'ah sehingga tertarik untuk menitipkan dananya terlebih lagi jika dilengkapi dengan sosialisi. Kedua, segi investor mungkin ada beberapa investor yang takut menanamkan modalnya karena bank tersebut baru berdiri. harus mampu menunjukkan bahwasannya mereka bisa berkembang sangat pesat dengan berbagai jasa pelayanan dan kinerja bank sangat baik dengan bukti yang rill agar mereka yakin. Ketiga, dari segi kerja sama MoU itu sangat di perlukan dalam permodalan BNI syari'ah perlu berkerjasama dari berbagai instansi untuk memperkuat permodalan selain kerja sama antar wilayah dalam negri akan lebih baik jika bekerjasama dengan bank di Negara lain dengan begitu selain memperluas fungsinya untuk melakukan pembayaran antar Negara atau yang lainnya. Hal tersebut akan sangat membantu apabila keadaan dalam negeri sedang tidak memungkinkan maka kita bisa menanggulanginya dari kerja sama luar negeri.

\section{PENUTUP}

Capital Adequacy Ratio (CAR) dari hasil perbandingan antara modal dan cadangan dengan aktiva beresiko di bank BNI Syari'ah sebesar 19,24\% dengan hasil presentase tersebut dinyatakan bahwasannya BNI syariah memenuhi ketentuan BIS karena presentase CAR yang di dapatkan melebihi ketentuan BIS yang sebesar 8\%. Maka dapat dikatakan BNI Syari'ah di nilai sehat.Dari hasil data tersebut BNI syari'ah memang dinilai sehat dari presentase CAR yang di dapatkan melebihi ketentuan BIS. Namun secara kasat mata BNI syari'ah harus meningkatkan lagi karena semakin tinggi CAR perbankan maka akan semakin baik. Sebab, bank tersebut akan punya kapasitas yang lebih besar untuk meminimalisir risiko sekaligus lebih mampu untuk ekspansi. Melalui beberapa cara antara lain Pertama, segi penghimpunan dana pihak ketiga dengan melakukan inovasi produk yang memungkinkan menunjuk sisi yang benar benar syari'ah dan meningkatkan efisiensi sistem perbankan syari'ah di era digital.Kedua, segi investor mungkin ada beberapa investor yang takut menanamkan modalnya karena bank tersebut baru berdiri BNi syari'ah mampu menunjukkan berbagai jasa pelayanan dan kinerja bank sangat baik dengan bukti yang rill agar mereka yakin. Ketiga, dari segi kerja sama MoU itu sangat di perlukan dalam permodalan BNI syari'ah perlu berkerjasama dari berbagai instansi untuk memperkuat permodalan bekerjasama dengan bank di Negara lain.

\section{DAFTAR PUSTAKA}

BNI Syari'ah. "Laporan Keuangan PT Bank BNI Syari'ah," diakse dari www.bnisyariah.co.id pada tanggal desember 2019.

Dendawijaya Lukman., Menajemen Perbankan. Bogor: Ghalia Indonesia, 2005.

Iqtishadia: Jurnal Ekonomi dan Perbankan Syariah

Vol. 7 No. 2 Desember 2020 
Suci Maugfiroh

Fena Ulfa Aulia. AKUNTANSI BANK SYARIAH BERDASARKAN PSAK 2007/ PAPSI 2013 KAJIAN TEORI DAN STUDI KASUS. Pamekasan: IAIN Madura, 2019.

Khaerul umam. Manajemen Perbankan Syariah. Bandung: CV Pustaka setia, 2013.

Mudrajat Kuncoro, and Suhardjono. Manajemen Perbankan. Yogyakarta: BPFE, 2011.

Muhammad Iqbal Fasa. "Manajemen Resiko Perbankan Syariah Di Indonesia." Li Falah: Journal of Islamic Economics and Business Studies 1.2 (2017): 36-53.

Seandy Nandadipa, and PRASETIONO. "Analisis Pengaruh CAR, NPL, Inflasi, Pertumbuhan DPK, Dan Exchange Rate Terhadap LDR (Studi Kasus Pada Bank Umum Di Indonesia Periode 2004-2008)'." Universitas Diponegoro, 2010.

Zainul Arifin. Dasar-Dasar Manajemen Perbankan Syariah. Jakarta: Alfabeta, 2002. 